\title{
Application of Learning Models of Concept Attainment and Problem Based Learning Against High School Students' Creative Thinking Ability on Redox Material
}

\author{
*Lisa N. M. Sakaria, Kasmudin Mustapa \& Anang W. M. Diah \\ Pendidikan Kimia/FKIP - Universitas Tadulako, Palu - Indonesia 94119 \\ Received 4 December 2020, Revised 8 January 2021, Accepted 3 February 2021 \\ doi: 10.22487/j24775185.2021.v10.i1.pp9-14
}

\begin{abstract}
Creative thinking is thinking to determine the new relationships between things, such as finding new solutions to a problem, finding new systems, and finding new artistic forms. This study aimed to analyze students' creative thinking ability by applying concept attainment and problem-based learning models in the redox material of class XSMA Negeri 9 Palu. This type of research was pre-experimental with the static group pre-test post-test design. This study used 2 classes, namely class X MIA 1 as experimental class $1(n=22)$ and class X MIA 2 as experimental class $2(n=22)$. Data analysis of students' creative thinking was performed using the test given after learning (post-test). The results of this study indicated that the percentage value of the average creative thinking of the experimental class 1 students was $74.5 \%$ with the high category and the achievement of aspects of creative thinking of students with the percentage from highest to lowest in the originality aspect were $76.7 \%$, flexibility aspect was $74.1 \%$, and the fluency aspect was $72.7 \%$. While the average percentage of experimental class 2 was $76.6 \%$ with the high category and the achievement of aspects of creative thinking of students with the highest to lowest percentage of the fluency aspect was $84.5 \%$, the originality aspect was $75.1 \%$, and the flexibility aspect was $70.2 \%$. The results of this study can be concluded that the application of the Concept Attainment and Problem Based Learning models were very good in creative thinking skills of students class in SMA Negeri 9 Palu on Redox material.
\end{abstract}

Keywords: Concept attainment, problem-based learning, creative thinking, redox

\section{Introduction}

Curriculum 2013 is an integrated effort between the reconstruction of graduation competencies, conformity and adequacy, depth and breadth of materials, learning revolution, and assessment reform (Firdaus, et al., 2016).

The 2013 curriculum has now been implemented in various schools in Central Sulawesi, one of which is SMA Negeri 9 Palu school in grade $\mathrm{X}$ of the 2017/2018 school year. Based on the results of an interview with one of the chemistry subject teachers in the school, the teachers have made learning innovations such as using lecture methods combined with discussions in line with the implementation of the 2013 curriculum. In fact, in the learning process, students still find difficulty in understanding some of the materials given, especially in chemistry subjects, this can be seen from the students' exam results and the lack of activeness of students in responding to teacher questions during the learning process. One of the materials considered difficult for students to understand is the oxidation-reduction reaction material (redox).
Studying abstract and mathematical redox reaction materials requires conceptual and algorithmic understanding (Aini, 2011). Abstract redox reaction material is suitable when given to students with a learning model that involves students actively and creatively in finding, analyzing, and developing concepts in redox reaction materials (Ekenobi, et al., 2016). The use of appropriate learning models is expected to encourage students' motivations, foster student activity, and increase students' creativity, as well as make it easier for students to understand the lessons to achieve better learning outcomes (Sari, et al., 2018).

The learning model needed to overcome the difficulty of understanding redox material in students is a model that fits the characteristics of the scientific approach. According to Putri, et al. (2014), the scientific approach is a recommended learning approach and a character of the 2013 curriculum. The procedure of application has stages that are to ask, try, associate, then communicate that is expected to produce qualified learners in the field of attitude, knowledge, and skills (Nurmasari, et al., 2014).

\footnotetext{
*Correspondence:

Lisa N. M. Sakaria

e-mail: sspd584@gmail.com

(c) 2021 the Author(s) retain the copyright of this article. This article is published under the terms of the Creative Commons Attribution License 4.0, which permits unrestricted non-commercial use, distribution, and reproduction in any medium, provided the original work is properly cited.
} 
The implementation of scientific approaches to redox reaction materials can apply problem-based learning models or problem based learning (PBL) models. This PBL model contains learning steps that involve students solving a problem given by the teacher. That expected students to be more active and creative and allow students to understand the subject matter, especially redox material, in the form of concepts and calculations better (Surya, et al. 2017).

Another learning model that can be applied to redox reaction material is the concept attainment learning model. The concept attainment learning model is a learning model that aims to help students understand a particular concept (Uno, 2008). The model was initially designed by Bruce (1992 to be prepared to develop inductive thinking, but also to analyze, develop, teach, and encourage students to be more effective in concept learning.

Applying these learning models is expected to improve students' creative thinking ability during the learning process on redox reaction materials.
Such thinking ability involves synthesizing ideas, building new ideas, and determining their effectiveness (Purwaningrum, 2016). Good creative thinking ability can master the students on abstract and mathematical redox material in the form of basic concepts and calculations so that students can more quickly and more easily understand the material in the sub-subject matter related to the concept of redox.

The present paper aims to give an analysis of the application of the concept attainment learning model and problem-based learning model on students' creative thinking ability in redox reaction material grade X SMA Negeri 9 Palu.

\section{Method}

The type of research used is pre experimental research. According to Sukmadinata (2012). The design used in this research is the static group pre-test post-test design. This design can be described in Table 1.

Table 1. Research design

\begin{tabular}{cccc}
\hline Group & Pre-test & $\begin{array}{c}\text { Treatment } \\
\text { (Variables free) }\end{array}$ & Post-test \\
\hline $\mathrm{E}_{1}$ & $\mathrm{X}_{1}$ & $\mathrm{Y}_{1}$ & $\mathrm{X}_{2}$ \\
$\mathrm{E}_{2}$ & $\mathrm{X}_{1}$ & $\mathrm{Y}_{2}$ & $\mathrm{X}_{2}$ \\
\hline
\end{tabular}

where $\mathrm{E}_{1}$ is Experiment Class $1 ; \mathrm{E}_{2}$ is Experimental Class 2; $\mathrm{X}_{1}$ is Pretest before learning; $\mathrm{X}_{2}$ is Posttest study chemistry; $\mathrm{Y}_{1}$ is Application of concept attainment learning model; $\mathrm{Y}_{2}$ is Implementation of problem-based learning model

This research was conducted at SMA Negeri 9 Palu, Jl. Hi Street. Patila, Pantoloan, North Palu, Palu City, Central Sulawesi. The population of this study is grade $\mathrm{X}$ students of SMA Negeri 9 Palu who enrolled in the 2017/2018 school year as many as 3 classes. The sample in this study consisted of 2 classes namely class X MIA 1 as experiment class 1 and class X MIA 2 as experiment class 2. Sampling techniques used in this research are purposive sampling techniques. Purposive sampling technique is a sampling technique with consideration (Noer, 2011). This technique was chosen based on the consideration that both sample groups had almost the same average ability. The number of students in both classes is the same as 22 students.

Free variables in this research are learning models used during the learning process, namely concept attainment learning models that will be applied to experiment class 1 and Problem Based Learning models that will be applied to experiment class 2 . The variable tied to this research is the creative thinking ability of grade X students of SMA Negeri 9 Palu on Redox material.

The type of data in this research is quantitative-qualitative data. According to Sukmadinata (2012) descriptive research is intended to describe or describe existing phenomena. This study describes students' creative thinking and quantitative data in this research, namely pretest and posttest creative thinking skills. The type of research data includes primary data sourced directly from students of grade X SMA N 9 Palu.

The data collection techniques in this study were obtained through the Creative Thinking test. This research was carried out in three stages, namely the preparation stage, the implementation stage and the final stage.

The instruments used in this study are, the test of creative thinking ability. The students' creative thinking ability test refers to creative thinking indicators in the form of descriptions and is judged based on students' answers and creative thinking rubrics. This creative thinking ability test is given before the learning process (pretest) and after the learning process using concept attainment model and problem-based learning model.

Data obtained from the results of research is data from the test of creative thinking ability. The following steps are taken in processing the data of the research results: Creative thinking ability test is analyzed through the students' answers to problems in the problem. The data obtained is then analyzed in a way: (1) Provides a raw score on each student's answer based on a rubik's assessment. (2) Calculate the test total score for each aspect of creative thinking. (3) Determine the percentage value of creative thinking for each aspect that appears in all 
students, with the following formula: Percentage $(\%)=($ Raw score obtained $) /($ Ideal maximum score $)$ x 100\% (Purwanto, 2010). Determine the level of creative thinking of students by analyzing the atacapability of two aspects of creative thinking. (4)
Sum the scores obtained by students from all given questions. (5) Convert the earned score into percentage form and categorize students' creative thinking abilities as in Table 2.

Table 2. Categories of creative thinking students

\begin{tabular}{cc}
\hline Student Creativity Value Interval (\%) & Student Creative Thinking Category \\
\hline $81 \% \leq N R \leq 100 \%$ & Very Hight \\
$61 \% \leq N R \leq 80 \%$ & High \\
$41 \% \leq N R \leq 60 \%$ & Are \\
$21 \% \leq N R \leq 40 \%$ & Low \\
$0 \% \leq N R \leq 20 \%$ & Very Low \\
\hline
\end{tabular}

\section{Results and Discussion}

The results obtained in this study are data during the teaching and learning process in grades $\mathrm{X}$ MIA 1 and X MIA 2 SMA Negeri 9 Palu by applying concept attainment learning models and problem-based learning models to students' creative thinking skills in aspects of fluency, flexibility, and originality.

The instrument used to measure the creative thinking of students in grade X SMA Negeri 9 Palu is a creative thinking test that amounts to 14 questions in the form of essays. The creative thinking test instrument has been validated by an expert validator; after being validated, the number of questions was 14 items, were declared valid and feasible for use in the research process. The validated problems consists of representing each aspect of creative thinking, among others, 5 questions for the fluency aspect, 4 questions for the aspect of flexibility, and 5 questions for the aspect of novelty. The selection of questions is adjusted to the learning indicators and indicators of every element of creative thinking.

The application of concept attainment learning models and problem-based learning models has the same treatment as the initial stage of observation, determining population and research samples, and drawing up a learning implementation plan (RPP). with an allocation of $3 \times 45$ minutes for 3 meetings. In the first meeting, a pretest was conducted with an allocation of 45 minutes or an hour of lessons and two hours of lessons for the learning process. At the second meeting, the learning process was based on RPP which had been arranged for three hours of lessons. At the third meeting, the two-hour learning process was conducted and posttested in the last hour of learning. The subject matter taught in both classes is redox material by applying the concept attainment learning model in experiment class 1, namely class X MIA 1, and problem-based learning model in experiment class 2, class X MIA 2.

Creative thinking is part of creativity which is the ability to submit ideas or ideas in solving a problem (Fardah, 2012). There are three aspects of creative thinking based on the Torrance Creative Thinking Test namely fluency, flexibility, and originality. The fluency aspect demands a large number of answers produced. The flexibility aspect requires a person to produce a varied idea so that there is no rigidity in thinking. While on the originality aspect, one is required to give a different answer than the other (Humaeroh, 2016). These three aspects of creative thinking are included in 14 points about creative thinking given to students when doing pretests and posttests.

The creative thinking ability of grade $\mathrm{X}$ students of SMA Negeri 9 Palu on redox material has increased. Based on the data from the study, it can also be known the percentage value of students' creative thinking through pretest and posttest in each class group studied, namely experiment class 1 , that is, the data can be described as in Figure 1 and 2.

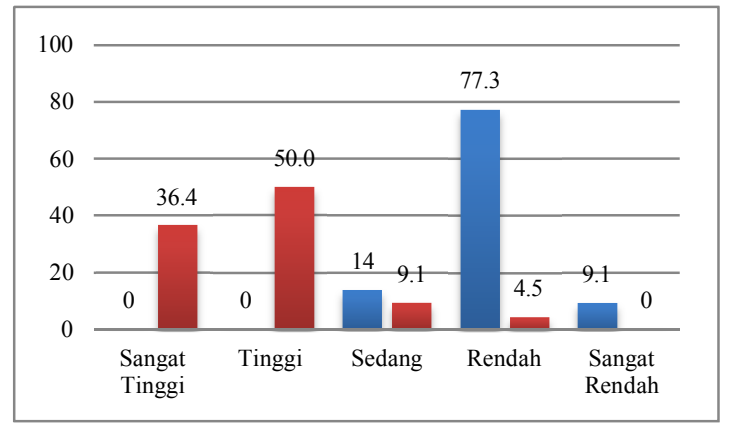

Figure 1. Creative thinking students experiment 1 


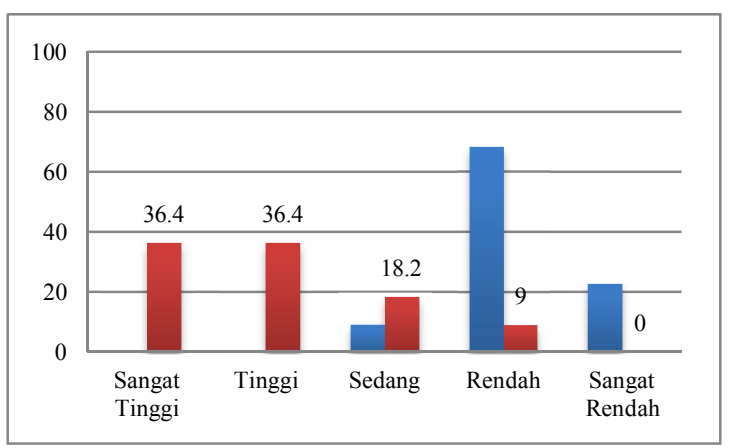

Figure 2. Creative thinking students experiment 2

The application of concept attainment learning models and problem-based learning models is very good and effective in building and improving students' creative thinking skills. Based on the results of analysis of pretest and posttest data of experimental class 1 and 2 with different treatment shows that the percentage of achievement of creative thinking level in experiment class 2 is more significant because when the pretest is seen more students with a very low level of creative thinking is $22.7 \%$ compared to the students of experiment 1 who have a very low level of creative thinking of $9.1 \%$. Whereas after posttest both classes the experiments were in the same category with a percentage that did not differ much. This is because in class 2 experiments with applied problem based learning models make students more active and creative in the process of problem discovery through a way that they can define problems by themselves in such a way that it involves them and the problem is relevant to their particular level and learning style (Ulger, 2018).

The application of concept attainment has a significant impact after posttesting. This is because the concept attainment model is a learning model that supports students' conceptual knowledge in defining concepts and the ability to describe components of concepts (Retno, et al., 2016). This model is intended to teach certain concepts by comparing and contrasting examples that contain concepts and do not contain concepts (Kumar \& Mathur, 2013). This learning model has the view that students are not only required to be able to form concepts through the process of collecting data, but they can also form concept arrangements with their own abilities (Putri, 2017).

The fluency aspect means being able to produce many relevant ideas/answers and have a smooth flow of thought (Munandar, 2012). Indicators of the aspect of fluency are asking a lot of questions, answering with a number of answers if there are questions, stories, or problems, applying a concept in different ways, thinking about various ways to solve the given problem (Munandar, 2004).

The flexibility aspect means being able to produce uniform ideas, able to change ways or approaches and have different directions of thought (Munandar, 2012). The indicator of flexibility aspect is to be able to see a problem from a different point of view, giving a variety of interpretations of an image, story, or problem (Munandar, 2004).

The originality aspect is the authenticity of the ideas produced in responding appropriately to ideas. Original thinking means giving unorthodox answers, other than others, and answers are rarely given by most people (Munandar, 2012).

Based on the data obtained, the average percentage of creative thinking of students in each aspect of experiment class 1 and experiment class 2 can be seen in Figure 3 and 4.

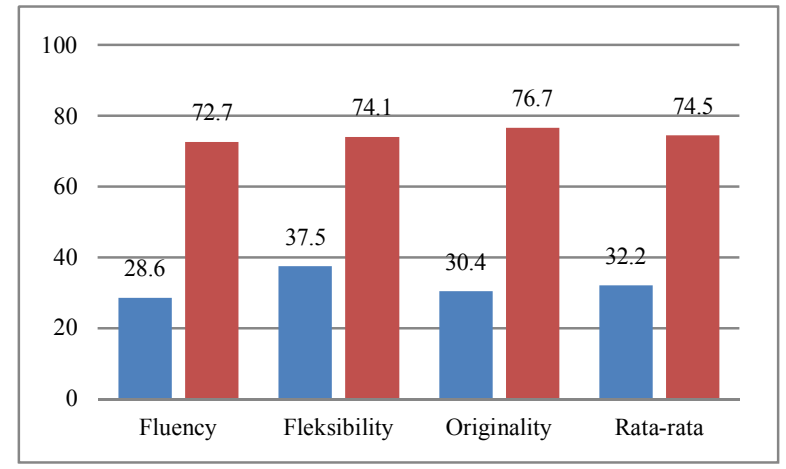

Figure 3. Creative thinking students experiment 1 


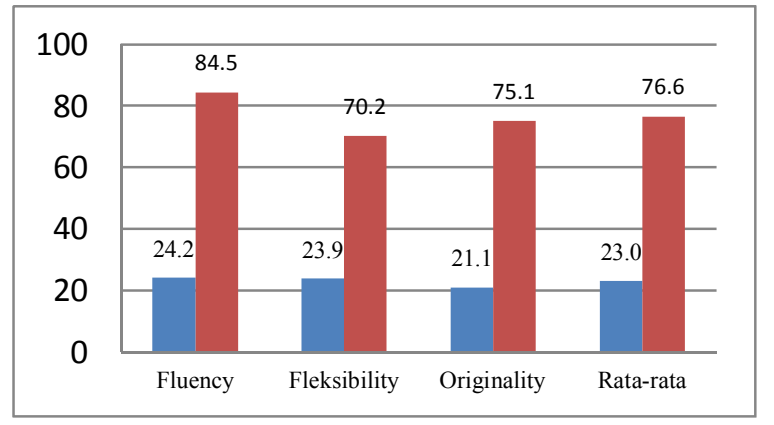

Figure 4. Creative thinking students experiment 2

As in Figure 3 and 4, shows that the application of concept attainment learning model in experiment class 1 is very good and effective to students' creative thinking ability with increasing level of creative thinking of students where the percentage before being given the application of concept attainment learning model percentage on average is in the low category of $30.4 \%$, after being given the application of concept attainment learning model the average percentage is in the high category of $74.5 \%$.

Basically the concept achievement model is also one of the current developing learning models to improve the level of student mastery (Wenno, et al., 2016). Therefore, there needs to be repeated and continuous training so that students are faster and better at achieving the concepts taught by the teacher and improving the thinking ability of the students. In applying this model, students are important to learn how to classification, how to think and how to accept certain concepts. So the role of teachers in the application of this model is to support and guide student assumptions (Ostad \& Soleymanpour, 2014)

The application of problem based learning model in experiment class 2 is very good and very effective to students' creative thinking ability with increasing level of creative thinking of students where the percentage before being given the application of problem based learning model the average percentage is in the low category of $23.0 \%$, after being given the application of problem based learning model the average percentage is in the high category of $76.6 \%$. While in each aspect of creative thinking, the two classes of experimentation have differences on the percentage of each aspect of the level of creative thinking. the achievement of creative thinking of students in class 1 experiments after being given learning (posttest) using the concept attainment learning model obtained percentage from the highest to the lowest in the aspect of originality of $76.7 \%$, flexibility aspect of $74.1 \%$ and aspect of originality of $72.7 \%$. While the achievement of creative thinking of students in experiment class 2 after being given posttest by using problem-based learning model obtained percentage from highest to lowest in fluency aspect of $84.5 \%$, originality aspect of $75.1 \%$ and flexibility aspect of $70.2 \%$.

Based on the description above, it can be concluded that the application of concept attainment learning model in the experimental class 1 is very good for students' creative thinking ability with increasing the level of creative thinking of students. Meanwhile the percentage before the application of concept attainment learning model the average percentage is in the low category of $30.4 \%$, after being given the concept attainment learning model the average percentage is in the high category of $74.5 \%$. The application of problem based learning model in experiment class 2 is very good for students' creative thinking ability with increasing level of creative thinking of students where the percentage before being given the application of problem based learning model the average percentage is in the low category of $23.0 \%$, after being given the application of problem based learning model the average percentage is in the high category of $76.6 \%$. While the achievement of the highest aspects of creative thinking of students in the application of concept attainment learning models in the experimental class 1 is found in the aspects of originality and the achievement of the highest aspects of creative thinking students in the application of problem-based learning models are in the fluency aspect.

\section{Conclusions}

Based on the results of the analysis of research data can be concluded that the percentage value $(\%)$ the average creative thinking of students in experiment grade 1 is $74.5 \%$ with high categories and the achievement of creative thinking aspects of students with the highest to lowest percentage in the originality aspect of $76.7 \%$, flexibility aspect of $74.1 \%$ and originality aspect of $72.7 \%$. While the average percentage of experiment class 2 is $76.6 \%$ with high category and achievement of creative thinking aspects of students with obtained percentage from highest to lowest in fluency aspect of $84.5 \%$, originality aspect of $75.1 \%$ and flexibility aspect of $70.2 \%$.

\section{Acknowledgements}

The author thanked Irsan as the head of SMA Negeri 9 Palu and Armin as a chemistry subject teacher of SMA Negeri 9 Palu and all parties who helped the author performe this research. 


\section{References}

Aini, F. N. (2011). Identifikasi pemahaman konseptual siswa kelas XII IPA-1 dan XII IPA-2 SMA negeri 6 Malang tahun ajaran 2010/2011 pada materi aplikasi reaksi redoks dan elektrokimia dalam kehidupan sehari-hari. Skripsi Tidak Diterbitkan. Malang: Universitas Negeri Malang.

Bruce, J. (1992). Models of teaching. Boston: Allyn and Bacon.

Ekenobi, T. N., Mumuni, A. A. O., \& Nwanekezi, A. U. (2016). Enhancing chemistry students' retention of redox reaction concept through intervention with advance organizers. British Journal of Psychology Research, 4(4), 34-46.

Fardah, D. K. (2012). Analisis proses dan kemampuan berpikir kreatif siswa dalam matematika melalui tugas open-ended. Jurnal Matematik Kreatif-Inovatif, 3(2), 1-9.

Firdaus., As'ari, A. R., \& Qohar, A. (2016). Meningkatkan kemampuan berpikir kreatif matematis siswa sma melalui pembelajaran open ended pada materi spldv. Jurnal Pendidikan Teori, Penelitian dan Pengembangan, 1(2), 227-236.

Humaeroh, I. (2016). Analisis kemampuan berpikir kreatif siswa pada materi elektrokimia melalui model open-ended problems. Skripsi Tidak Diterbitkan. Jakarta: Universitas Islam Negeri Syarif Hidayatullah.

Kumar, A., \& Mathur, M. (2013). Effect of concept attainment model on acquisition of physics concepts. Universal Journal of Educational Research, 1(3), 165-169.

Munandar, S. C. U. (2004). Pengembangan kreativitas anak berbakat. Jakarta: PT Rineka Cipta.

Munandar, S. C. U. (2012). Pengembangan kreativitas anak berbakat. Jakarta: Rineka Cipta.

Noer, S. H. (2011). Kemampuan berpikir kreatif matematis dan pembelajaran matematika berbasis masalah open-ended. Jurnal Pendidikan Matematika, 5(1), 104-111.

Nurmasari, N., Kusmayadi, T. A., \& Riyadi. (2014). Analisis berpikir kreatif siswa dalam menyelesaikan masalah matematika pada materi peluang ditinjau dari gender siswa kelas XI IPA SMA negeri 1 kota Banjarbaru Kalimantan selatan. Jurnal Elektronik Pembelajaran Matematika, 2(4), 351-358.

Ostad, G., \& Soleymanpour, J. (2014). The impact of concept attainment teaching model and mastery teaching method on female high school students' academic achievement and metacognitive skills. International Journal of Innovative Research in Science, Engineering and Technology, 3(2), 9774-9781.

Purwaningrum, J. P. (2016). Mengembangkan kemampuan berpikir kreatif matematis melalui discovery learning berbasis scientific approach. Jurnal Refleksi Edukatika, 6(2), 145-157.

Purwanto, N. (2010). Prinsip-prinsip dan teknik evaluasi pengajaran. Bandung: PT Remaja Rosdakarya.

Putri, C. A. I., Putra, K. N. D., \& Zulaikha, S. (2014). Pengaruh metode pembelajaran SQ3R terhadap hasil belajar bahasa Indonesia kelas $\mathrm{V}$ SD. Mimbar PGSD Universitas Pendidikan Ganesha, 2(1), 1-11.

Putri, D. P. (2017). Model pembelajaran concept attainment dalam meningkatkan pemahaman konsep matematika. Jurnal Pemikiran dan Penelitian Pendidikan, 15(1), 97-130.

Retno, Y., Rusdi., \& Amalia. (2016). Pengaruh model pembelajaran concept attainment terhadap kemampuan komunikasi dan pemahaman konsep siswa pada materi sistem reproduksi. Jurnal Pendidikan Biologi, 9(2), 15.

Sari, D. K., Banowati, E., \& Purwanti, E. (2018). The effect of problem-based learning model increase the creative thinking skill and students activities on elementary school. Journal of Primary Education, 7(1), 57-63.

Sukmadinata, N. S. (2012). Metode penelitian pendidikan. Bandung: PT. Remaja Rosdakarya.

Surya, E., Dermawan, D. A., \& Syahputra, E. (2017). The efforts to improving the creative thinking ability through problem-based learning of junior high school students. International Journal of Novel Research in Education and Learning, 4(2), 29-40.

Ulger, K. (2018). The effect of problem-based learning on the creative thinking and critical thinking disposition of students in visual arts education. Interdisciplinary Journal of ProblemBased Learning, 12(1), 1-20.

Uno, H. B. (2008). Model pembelajaran. Jakarta: Bumi Aksara.

Wenno, I. H., Wattimena, P., \& Maspaitela, L. (2016). Comparative study between drill skill and concept attainment model towards physics learning achievement. International Journal of Evaluation and Research in Education, 5(3), 211-215. 